and prohibition as 'usually appropriate in cases of adultery', such a penalty may also be appropriate in cases such as this one where the misconduct had fallen short of adultery. The court upheld the tribunal's finding that the appellant was guilty of serious misconduct and that the penalty imposed was appropriate. The court found that the tribunal had given proper regard to the evidence before them of the appellant's character and pastoral skills, and noted that the appellant had at no time shown repentance or remorse. The court held that there was a distinction between the bishop's discretionary power to suspend a priest during proceedings under the Measure and a penalty imposed by the tribunal for proven misconduct. The court stated that 'we do not consider that a period of suspension should be taken into account when a disciplinary tribunal, or this court, is determining the appropriate penalty in a particular case'. In this case, the period of prohibition was ordered to begin on the date of the confirmation of the penalty by the Chancery Court. [WA]

doi:10.1017/So956618Xo8001579

\title{
Re Cotes
}

Lichfield Consistory Court: Coates Ch, May 2008

Plate - gift - proprietary interest

In 1660 , an ancestor of the petitioner gifted four pieces of plate to St Peter's, Woodcote unconditionally. In February 2007, the church was deconsecrated. Technically, the church is still in use because the necessary pastoral scheme has not been put into effect. The petitioner, who did not live in the parish, petitioned for a faculty to gift three of the items in question to the church of St James, Cotes Heath and for the fourth item, a silver flagon, to be given to himself. Neither the parish nor the Council for the Care of Churches supported the application, and the DAC made no comment. The chancellor ruled that the petitioner had no proprietary interest in the items. Even if the petitioner did have a proprietary interest in the plate, the chancellor ruled that he would still not grant a faculty for any item to be 'gifted' in the way requested to a private individual without there being an extremely good reason for doing so. No such good reason had been advanced here. The petition was dismissed. [JG]

doi:10.1017/So956618Xo8001580.

\section{Re St Giles, Shrewsbury}

Lichfield Consistory Court: Coates Ch, May 2008

Font - repositioning - necessity

The petitioners sought to move the font from the south door to a position on the north wall adjacent to the Lady Chapel and to remove five pews from the north 
and south aisles. The reasons given were that the font was a major obstruction by the south door and that the position necessitated the congregation turning around to see what was going on. The chancellor considered Canon F1, paragraph 2, and the decision in Re St Luke the Evangelist, Maidstone [1995] Fam 1, [1995] 1 All ER 321, Ct of Arches, and concluded that neither 'necessity' nor a 'good case for change' had been made out. The font could be repositioned by the south door and the removal of the pews would allow more space for the congregation to gather round the font. The petition in relation to the font was dismissed. [JG] 